\title{
Highly active antiretroviral therapy increases fibrinolytic and protein activity in pregnant women
}

\author{
Evarista Odaburhine Osime * and Catherine Obar *
}

\begin{abstract}
\section{BACKGROUND}

Various studies have examined optimal methods for Prevention of Mother to Child Transmission (PMTCT) of human immunodeficiency virus (HIV) and subsequent outcome of response to highly active antiretroviral therapy (HAART) as well as the impact of pregnancy on outcomes of HIV in the Pre-HAART era. Little is known of the impact of pregnancy in response to HAART in Africa. This study is aimed to evaluate euglobulin lysis time (ELT), protein C and protein S in HIV-positive pregnant women on HAART.
\end{abstract}

\section{METHODS}

This was a cross-sectional study comprised of 150 participants attending Ante-Natal Clinic (ANC) in Central Hospital, Benin City. Pregnant women on HAART (Test subjects) ( $\mathrm{n}=50$, mean age 34 years), 50 pregnant newly diagnosed HIV-positive women that had not yet commenced HAART ( $\mathrm{n}=50$, mean age 31 years) and 50 pregnant HIV-negative women $(n=50$, mean age 30 years) which served as controls. The ELT was determined by methods described by Bain, protein $\mathrm{C}$ and protein $\mathrm{S}$ were determined using Enzyme Linked Immunosorbent Assay (ELISA).

\section{RESULTS}

There was a significant increase in ELT in both pregnant women on HAART and not on HAART) when compared to HIV-negative pregnant women $(\mathrm{p}<0.05)$. There was a significant decrease in protein $\mathrm{C}$ in test subjects when compared with controls $(\mathrm{p}<0.05)$ and protein $\mathrm{S}$ increased significantly in HIV-positive pregnant women on HAART when compared to those not on HAART and HIV-negative pregnant women $(\mathrm{p}<0.05)$.

\section{CONCLUSION}

There are changes in ELT, protein $\mathrm{C}$ and protein $\mathrm{S}$ parameters with the introduction of HAART in pregnancy.

Keywords: Pregnancy, HIV, HAART, PMTCT, euglobulin lysis time, protein $\mathrm{C}$, protein $\mathrm{S}$.
*Department Of Medical Laboratory Science

School Of Basic Medical Sciences College Of Medical Sciences University Of Benin

Correspondence: Dr (Mrs) E.O. Osime Department Of Medical Laboratory Science

School Of Basic Medical Sciences College Of Medical Sciences

University Of Benin

Phone Number: 08033607898

Email: evarista.osime@uniben.edu

Date of first submission, May 7, 2018 Date of final revised submission, August 23, 2018

Date of acceptance, August 27, 2018

This open access article is distributed under a Creative Commons AttributionNon Commercial-Share Alike 4.0 International License

Cite this article as: Osime EO, Obar C. Highly active antiretroviral therapy increases fibrinolytic and protein activity in pregnant women. Univ Med 2018; 37:181-7. doi: 10.18051/UnivMed. 2018.v37.181-187 


\section{INTRODUCTION}

It has been ascertained that a significant proportion of human immunodeficiency virus (HIV)-positive adults who require antiretroviral therapy (ART) are women of childbearing age. ${ }^{(1)}$ More often, HIV infection in women is diagnosed for the first time during a pregnancy, and an estimated 1.38 million pregnant women in low- and middle-income countries of subSaharan Africa are living with HIV.(2) Human immunodeficiency virus can be transmitted from an HIV-positive mother to her child during pregnancy, childbirth and breast feeding. Mother-to-child transmission (MTCT) accounts for over $90 \%$ of new HIV infections among children and an estimated 1.6 million new HIV infections among children have been prevented due to the availability of antiretroviral medicines. ${ }^{(3)}$ Human immunodeficiency virus infection is a global burden and rapidly spreading. It is responsible for significant morbidity and mortality by various mechanisms and one among them is coagulation abnormalities. There are uncertainties in pathologies of coagulation abnormalities in HIV patients. ${ }^{(4)}$

Amongst these are hepatic damage which may be caused by the virus itself or by the administration of anti-retroviral (ARV) drugs such as nevirapine which may also contribute to coagulation defects in these patients. Platelets play an important role in the hemostatic process, however platelets have been shown to decrease in HIV infection due to autoimmune destruction, direct infection of megakaryocytes by the virus and consumption coagulopathy occurring in acquired immune deficiency syndrome (AIDS). ${ }^{(6)}$ Pregnancy is a state of hypercoagulation, which is an adaptive mechanism to reduce the risk of haemorrhage during and after the delivery. Although a lot of studies have been carried out on the prevention of MTCT of HIV and subsequent response to HAART, there is paucity of information on the impact of HAART on pregnancy in Africa. Specifically no work has been done on ELT, protein S and protein C in
Africa. The World Health Organization released new guidelines recommending lifelong ART for all pregnant and breastfeeding women living with HIV. ${ }^{(7)}$ The guidelines recommended option B, where lifelong ART is provided to all pregnant and breastfeeding women living with HIV regardless of CD4 count or WHO clinical stage. The American National Institute of Health and other organizations encourage offering antiretroviral treatment to all patients with AIDS. United States of America and European guidelines strongly recommend antiretroviral drug initation if the CD4 count is less than 500 cells $/ \mathrm{mm} 3$, with the urgency of ART increasing as the CD4 count declines. ${ }^{(8,9)}$

Antiretroviral therapy has been found to improve haematocrit values ${ }^{(10-12)}$ and presents a marked increase in tissue plasminogen activator antigen (t-PA) and plasminogen activator inhibitor type I (PAI) levels, demonstrating that antiretroviral drugs lead to fibrinolytic changes contributing significantly to haemorrhage. ${ }^{(13)}$ Pregnancy is associated with widespread changes in haemostasis such that the procoagulant effect becomes dominant. These changes include increase in concentration of most clotting factors, decreasing concentrations of some of the natural anticoagulants and diminishing fibrinolytic activity. ${ }^{(14)}$ Although a lot of studies have been carried out on the prevention of MTCT of HIV and subsequent response to HAART, there is paucity of information on the impact of HAART on pregnancy in Africa. Specifically no work has been done on euglobulin lysis time (ELT), protein $\mathrm{S}$ and protein $\mathrm{C}$ in Africa. This study revealed the possible effect of the use of lifelong ART by pregnant women on some haemostatic parameters.

\section{METHODS}

\section{Research Design}

This cross-sectional study was conducted in the Central Hospital in Benin city, Edo state and the Central Hospital in Delta state which are 
both situated in the South-South geopolitical zones. This study was carried out in Central Hospital Pathology units and University of Benin Teaching Hospital (UBTH) pathology units between May and November 2016.

\section{Research subjects}

This study comprised 150 participants consisting of 50 pregnant women on HAART, 50 pregnant women newly diagnosed to be positive to HIV antibodies but have not commenced HAART and 50 HIV-negative pregnant women who served as controls. The sample size required per group to compare means of ELT at $\alpha=0.05$, power $=0.80$ and effect size 0.50 was 50 per group. ${ }^{(15)}$ The selection process using informed consent was initiated at the HIV Prevention, Treatment and Care (PMTCT) clinic where HIV seropositive pregnant women were enrolled after counselling for the test group and the ANC for the control group over a period of seven months. The test and control participants were matched for age. Inclusion criteria were pregnant women confirmed to be HIV-positive and to have no previous history of coagulopathy, and have commenced HAART. Exclusion criteria were pregnant women with diabetes mellitus or hypertension.

\section{Sample collection}

Eight milliliters of venous blood was obtained from the cubital fossa of each participant using vacutainers. Four milliliters each was dispensed into EDTA and sodium citrate vacutainers and well mixed. All samples were analysed within 4 hours post collection.

\section{Laboratory analysis}

Euglobulin lysis time (ELT) was determined using the method described by Bain et al. ${ }^{(14)}$.To $9.5 \mathrm{~mL}$ of $1 \%$ acetic acid in a test tube, $0.5 \mathrm{~mL}$ of plasma was added and the tube kept at $4^{\circ} \mathrm{C}$ for 30 minutes to precipitate the euglobulin fraction. The tube was then centrifuged at $2000 \mathrm{rpm}$ for $10 \mathrm{~min}$. The supernatant was discarded and the tube was inverted to remove the acetic acid completely. The deposit was re-constituted with $0.5 \mathrm{ml}$ borate buffer (Sodium borate $1 \mathrm{~g}$, Sodium chloride $9 \mathrm{~g}$, and distilled water $100 \mathrm{~mL}$ ). The tube was pre-warmed at $37^{\circ} \mathrm{C}$ alongside calcium chloride $(0.025 \mathrm{M})$ for $2 \mathrm{~min}$, and $0.5 \mathrm{ml}$ of the calcium chloride was added to the tube containing the deposit and borate buffer. A stop watch was started after a clot was observed and the time for the euglobulin fraction to lyse completely was recorded in minutes.

Protein $\mathrm{S}$ and $\mathrm{C}$ were measured using ELISA techniques, where anti-protein $\mathrm{C}$ fragments were adsorbed to polystyrene plates. The binding of serial dilutions of control and test plasma containing protein $\mathrm{C}$ was detected by incubation with peroxidase-labeled anti-protein CIgG followed by the addition of hydrogen peroxide and O-phenylenediamine.

A polyclonal antibody specific for human protein S was pre-coated onto a 96-well microplate with removable strips. Protein $\mathrm{S}$ standard and samples were competed by a biotinylated protein $\mathrm{S}$ sandwiched by the immobilized antibody and streptavidin peroxidase conjugate. All unbound material was washed away and a peroxidase enzyme substrate was added. The colour development was stopped and the intensity of the colour was measured using an ELISA reader.

Packed cell volume (PCV) was determined using the micro-haematocrit method. Mixed blood sample from the EDTA container was introduced into a non-heparinized capillary tube filled to twothird capacity. It was flame-sealed at one end, placed in a microhaematocrit centrifuge, and spun at 10,000 RPM for 5 minutes. The volume of packed red blood cells was then read from a haematocrit reader.

Haemoglobin $(\mathrm{Hb})$ concentration was measured using the cyanmethaemoglobin method. Five milliliters of Drabkin's solution (potassium cyanide and potassium ferricyanide) was mixed carefully with $0.5 \mathrm{~mL}$ of venous blood in a test tube, and the absorbance read at $540 \mathrm{~nm}$ using a colourimeter. The $\mathrm{Hb}$ concentration was then extrapolated from a standard calibration chart. 
Table 1. Distribution of feature variables by test and control group

\begin{tabular}{|c|c|c|c|c|}
\hline Variables & $\begin{array}{c}\text { HIV }(+) \text { pregnant } \\
\text { women on } \\
\text { HAART }(n=50)\end{array}$ & $\begin{array}{c}\text { HIV (+) pregnant } \\
\text { women not on } \\
\text { HAART }(n=50)\end{array}$ & $\begin{array}{c}\text { HIV-negative } \\
\text { pregnant women } \\
(n=50)\end{array}$ & p value \\
\hline Age (years) & $34.50 \pm 0.70$ & $32.60 \pm 0.41$ & $31.40 \pm 0.41$ & 0.000 \\
\hline History of clotting disorder & 0 & 0 & 0 & \\
\hline \multicolumn{5}{|l|}{ Blood pressure (mmHg) } \\
\hline Systolic & $134.70 \pm 2.78$ & $128.68 \pm 1.71$ & $121.04 \pm 2.14$ & 0.000 \\
\hline Diastolic & $86.80 \pm 1.46$ & $81.24 \pm 1.55$ & $79.12 \pm 1.98$ & 0.032 \\
\hline Gestational age (weeks) & $22.12 \pm 1.98$ & $19.80 \pm 1.46$ & $18.22 \pm 1.04$ & 0.672 \\
\hline
\end{tabular}

\section{Statistical analysis}

Data were analysed using the Statistical Package for Social Sciences (SPSS Version 20) and expressed as mean \pm standard deviation. Student's t test and analysis of variance (ANOVA) were used in comparing mean values between and among groups, respectively. A post-hoc multiple comparison Tukey test was used to determine which means differ. A p-value less than 0.05 at $95 \%$ confidence limit was considered as significant.

\section{Ethical clearance}

Verbal informed consent was obtained from all participants as well as ethical approval from the Ethics and Research Committee of the Edo State Hospital Management Board, under Reference Number A732/T/33 and Delta State Hospital Management Board under Reference Number CHW/ECC Vol1/091.

\section{RESULTS}

Demographic indices of HIV-positive pregnant women on HAART, pregnant HIVpositive women not on HAART and pregnant HIV-negative women are indicated in Table 1.
All the participants were females within the age range of 27-36 years, of different ethnic groups and had no history of clotting disorders. The HIV-positive pregnant women on HAART had a significantly higher age difference when compared to HIV-positive women not on HAART and pregnant HIV-negative women. The mean systolic and diastolic blood pressure of HIV-positive pregnant women on HAART and HIV-positive women not on HAART was significantly higher than pregnant HIV-negative women $(p=0.000 ; p=0.032)$.

There was a significant reduction in $\mathrm{PCV}$ and $\mathrm{Hb}$ in HIV-positive women on HAART and those not on HAART when compared to HIV-negative pregnant women $(p<0.05)$. The ELT increased significantly $(\mathrm{p}<0.05)$, coagulation protein $\mathrm{C}$ reduced significantly $\mathrm{p}<0.05$ (Table 2 ).

In HIV-positive women on HAART and HIV-positive women who had not yet commenced HAART there were significant differences in PCV, haemoglobin concentration $(\mathrm{Hb})$ and protein $\mathrm{C}(\mathrm{p}<0.05)$, while protein $\mathrm{S}$ was significantly reduced in pregnant women not on HAART when compared to those on HAART $(\mathrm{p}<0.05)$. There was no significant difference

Table 2. Distribution of studied parameters in test and control subjects

\begin{tabular}{lllll}
\hline \multicolumn{1}{c}{ Parameters } & $\begin{array}{c}\text { HIV (+) women on } \\
\text { HAART }(\mathbf{n}=\mathbf{5 0})\end{array}$ & $\begin{array}{c}\text { HIV }(+) \text { women not } \\
\text { on HAART }(\mathbf{n}=\mathbf{5 0})\end{array}$ & $\begin{array}{c}\text { HIV (-) pregnant } \\
\text { women }(\mathbf{n}=\mathbf{5 0})\end{array}$ & p value \\
\hline $\mathrm{PCV}(\%)$ & $26.6 \pm 0.24$ & $27.27 \pm 0.07$ & $34.34 \pm 1.56$ & 0.002 \\
$\mathrm{Hb}(\mathrm{g} / \mathrm{dL})$ & $8.87 \pm 1.83$ & $9.01 \pm 0.62$ & $11.48 \pm 0.71$ & 0.037 \\
$\mathrm{ELT}(\mathrm{mins})$ & $354 \pm 8.12$ & $356 \pm 11.6$ & $296 \pm 10.13$ & 0.000 \\
Protein $\mathrm{C}(\mu \mathrm{g} / \mathrm{mL})$ & $1.34 \pm 0.87$ & $1.12 \pm 0.75$ & $2.02 \pm 0.88$ & 0.000 \\
Protein $\mathrm{S}(\mu \mathrm{g} / \mathrm{mL})$ & $13.82 \pm 6.25$ & $10.02 \pm 4.67$ & $13.09 \pm 5.36$ & 0.010 \\
\hline
\end{tabular}

Data presented as Mean $\pm \mathrm{SD}$; PCV: packed cell volume, Hb: hemoglobin; ELT: euglobulin lysis time; HIV: human immunodeficiency virus; HAART: highly active antiretroviral therapy 
Table 3. Tukey multiple comparison test

\begin{tabular}{llcc}
\hline \multicolumn{1}{c}{ Parameters } & Mean differences & p value \\
\hline PCV & HIV (+) not on HAART & & 0.004 \\
HIV $(+)$ on HAART & HIV (-) & -1.600 & 0.000 \\
& HIV (-) & -7.800 & 0.000 \\
HIV $(+)$ not on HAART & -6.200 & 0.003 \\
Hb & HIV (+) not on HAART & -1.600 & 0.000 \\
HIV $(+)$ on HAART & HIV (-) & -2.833 & 0.000 \\
HIV $(+)$ not on HAART & HIV (-) & -2.233 & 0.952 \\
ELT & HIV (+) not no HAART & -3.133 & 0.000 \\
HIV $(+)$ on HAART & HIV (-) & 72.300 & 0.000 \\
HIV $(+)$ not on HAART & HIV (-) & 75.433 & 0.017 \\
Protein C & HIV (+) not on HAART & & 0.035 \\
HIV $(+)$ on HAART & HIV (-) & 0.667 & 0.000 \\
HIV $(+)$ not on HAART & HIV (-) & -0.600 & 0.000 \\
Protein S & HIV (+) not on HAART & -1.267 & 0.597 \\
HIV $(+)$ on HAART & HIV (-) & 0.800 & 0.001 \\
HIV $(+)$ not on HAART & HIV (-) & 0.167 & -0.633 \\
\hline
\end{tabular}

Note : PCV: packed cell volume, Hb: hemoglobin; ELT: euglobulin lysis time; HIV: human immunodeficiency virus; HAART: highly active antiretroviral therapy

in ELT in HIV $(+)$ on HAART when compared to HIV $(+)$ not on HAART $(p=0.952)($ Table 3$)$.

\section{DISCUSSION}

Human immunodeficiency virus infection is a global burden and rapidly spreading. It causes significant morbidity and mortality by various mechanisms and one among them is coagulation abnormalities. This is quite a serious complication especially in the late stage of HIV infection and there are uncertainties in pathogenesis of coagulation abnormalities in HIV subjects. ${ }^{(16)}$ In this study, there was a significant increase in the ages of HIV pregnant women on HAART and those newly diagnosed who had not yet commenced HAART prior to sample collection when compared to the HIVnegative women. This suggests that these groups of women are getting pregnant later than their seronegative counterpart. This may be attributed to the transient depression encountered by these women when their HIV status is first discovered. But as they receive counselling and monitoring, they get encouraged to want to have babies and live healthy normal lives. Blood pressure was observed to increase significantly in HIV-positives on HAART and those not on HAART when compared to HIV seronegative women. This may be physiological and stigmatization may be a contributing factor especially in this part of the world. The transformation of the HIV epidemic over the last 20 years has been remarkable; with access to appropriate therapies, clinicians can now offer infected women a much improved prognosis as well as a very high likelihood of birthing children who will be HIV-uninfected.

In this study, it was observed that HIVinfected pregnant women on HAART and those not on HAART had significantly lower $\mathrm{Hb}$ and PCV values compared with the controls $(p<0.05)$. Although HAART has been observed to increase $\mathrm{PCV},{ }^{(17)}$ the reduced PCV observed in this study may be attributed to the HIV virus and non-compliance to the antiretroviral drugs regularly as observed from interaction with the participating women during sample collection. Protein C levels were observed to reduce more in HIV-positive pregnant women not on HAART therapy than those on therapy, but were significantly reduced when both were compared 
to HIV seronegative pregnant women $(\mathrm{p}<0.05)$. This may be attributed to the large amounts of antiphospholipid antibodies produced during HIV infection which inactivates protein $\mathrm{C} .{ }^{(18)}$ Protein $\mathrm{C}$ and its cofactor protein $\mathrm{S}$ exert their coagulation activity primarily through inactivation of coagulation factor Va and VIIIa which are required for factor $\mathrm{X}$ activation and thrombin generation. ${ }^{(19)}$ The catalytic activity of protein $\mathrm{C}$ is enhanced by the vitamin-K-dependent cofactor, deficiency of which distorts the delicate balance between procoagulant and anticoagulant proteins, thus introducing a prothrombotic state. ${ }^{(20)}$

Also in this study, protein $\mathrm{S}$ was significantly increased in HIV-positive women on HAART, when compared to those not on HAART and HIV seronegative women. This may be attributed to the direct effect of antiretroviral therapy.

There was a significant increase in ELT in HIV-positive pregnant women on HAART and those not on HAART when compared with HIV seronegative women. This could be attributed to the side effects of HAART on those individuals, some of which may be directly connected to HIV protease inhibitors. Several studies have linked HIV protease inhibitors with the activation of endoplasmic reticulum stress and oxidative stress as well as increase in inflammatory cytokine production from several cell types including macrophages and intestinal epithelial cells. ${ }^{(21,22)}$

A limitation of this study was the difficulty in having these women to participate in this study. Their willingness to be enrolled for the study was very low. Regular monitoring of ELT, protein $\mathrm{C}$ and protein $\mathrm{S}$ levels is therefore recommended when HIV pregnant women are being treated with antiretroviral drugs.

\section{CONCLUSION}

Increased ELT and decreased protein C levels were observed in HIV-positive pregnant women on HAART and those not on HAART, while protein S level is improved with the administration of HAART.

\section{CONFLICT OF INTEREST}

We declare that there is no conflict of interest.

\section{ACKNOWLEDGEMENT}

We acknowledge the management of Central Hospital, Benin City and Delta State Hospital Management Board for granting us the ethical approval and allowing access to the patients. We are also grateful to the doctors and nurses who assisted in blood sample collection.

\section{FINANCIAL DISCLOSURE}

This work was self-sponsored.

\section{CONTRIBUTORS}

OE contributed to design supervision and write up of this manuscript. OC contributed to sample collection and analysis. All authors have read and approved the final manuscript.

\section{REFERENCES}

1. Raman RT, Manimaran P, Rachakatla K, et al. Study of basic coagulation parameters among HIV patients in correlation to CD4 and ART status. J Clin Diagn Res 2016;10:E-4-6. doi: 10.7860/JCDR/ 2016/17459.7718.

2. Sturt AS, Dokubo EK, Sint T. Antiretroviral therapy (ART) for treating HIV infection in ARTeligible pregnant women. Cochrane Database Syst Rev 2010;3:CD008440. doi: 10.1002/14651858. CD008440.

3. World Health Organization. Guideline on when to start antiretroviral therapy and on pre-exposure prophylaxis for HIV. Geneva: World Health Organization; 2015.

4. Nasir IA, Owolagba A, Ahmad AE, et al. Effects of first-line anti-retroviral therapy on blood coagulation parameters of HIV-infected patients attending a tertiary hospital at Abuja, Nigeria. Malaysian J Pathol 2016;38:103-9. 
5. Pau AK, George JM. Antiretroviral therapy: current drugs. Infect Dis Clin North Am 2014;28: 371-402. doi: 10.1016/j.idc.2014.06.001.

6. Simmonds MJ, Meiselman HJ, Baskurt OK. Blood rheology and aging. J Geriatr Cardiol 2013;10: 291301. doi: 10.3969/j.issn.1671-5411.2013.03.010.

7. Bositis CM, Gashongore I, Patel DM. Updates to the World Health Organization's recommendations for the use of antiretroviral drugs for treating pregnant women and preventing HIV infection in infants. Med J Zambia 2010;37:111-7.

8. Bartlett TA, Michael FT, Demasi RH, et al. An updated systemic overview of triple combination therapy in antiretroviral-naive HIV-infected adults. AIDS;2010:20;2051-64.

9. Thompson MA, Aberg JA, Hoy JF, et al. Antiretroviral treatment of adult HIV infection: recommendations of the International Antiviral Society-USA Panel. JAMA. 2012;308:387-402. doi: 10.1001/jama.2012.7961.

10. Odunukwe $\mathrm{N}$, Idigbe $\mathrm{O}$, Kanki $\mathrm{P}$, et al. Haematological and biochemical response to treatment of HIV-1 infection with a combination of nevirapine +stavudne+lamivudine in Lagos, Nigeria. Turkish J Hematol 2009;22:125-31.

11. Omoregie R, Osakue SI, Ihemeje V, et al. Correlation of CD4 count with platelet count, prothrombin time and activated partial thromboplastin time among HIV patients, Benin City, Nigeria. West Indian Med J 2009:58:437-40.

12. Pintao M, Garcia A, Borgel D, et al. Detection duplication in PROST is relatively common in point mutation negative hereditary protein $\mathrm{S}$ deficiency. Hum Genet 2009:126:449-56.

13. Marks KM, Clarke RMA, Bussel JB, et al. Risk factors for thrombocytopenia in HIV-infected persons in the era of potent antiretroviral therapy. J Acquir Immune Defic Syndr 2009;52:595-9. doi: 10.1097/QAI.0b013e3181b79aff.
14. Bain BJ, Bates I, Laffan AM. Dacie and Lewis practical haematology. $12^{\text {th }}$ ed. Philadelphia: Elsevier;2017.

15. Browner WS, Newman TB, Hulley SB. Estimating sample size and power: applications and examples. In: Hulley SB, Cummings SR, Browner WS, Grady DG, Newman TB, editors. Designing clinical research. $4^{\text {th }}$ ed. Philadelphia: Lippincott Williams \& Wilkins;2013.

16. Bibas M, Biava G, Antinori A. HIV-associated venous thromboembolism. Mediterr J Hematol Infect Dis 2011;3:e2011030. doi: 10.4084/MJHID. 2011.030.

17. lbeh BO, Omodamiro DO, lbeh U, et al. Biochemical and haematological changes in HIV subjects receiving winniecure antirethroviral drug in Nigeria. J Biomed Sci 2013;20:73. https://doi.org/ 10.1186/1423-0127-20-73.

18. Katz D, Beilin Y. Disorders of coagulation in pregnancy .Br J Anaesth 2015;115 Suppl 2:ii7588. doi: 10.1093/bja/aev374.

19. Eyal A, Veller M. HIV and venous thrombotic events. South African J Surg 2009;47:93-5.

20. Osime EO, Onakewhor JU, Kolade SO. Fibrinolytic changes in pregnant women on highly active antiretroviral therapy. Saudi Med J 2015;36:2003.

21. Gahir S, Anger GT, Ibrahim M, et al. Management of HIV positive pregnancies in Ontorio: current status. Canadian J Clin Pharmacol 2009; 16:68-77.

22. Danese S, Vetrano S, Zhang L, et al. The protein $\mathrm{C}$ pathway in tissue inflammation and injury: pathogenic role and therapeutic implications. Blood 2010; 115:1121-30. doi: 10.1182/blood-200909-201616. 